\title{
PENGARUH STRUKTUR KEPEMILIKAN, STRUKTUR MODAL, DAN KEBIJAKAN DIVIDEN PADA NILAI PERUSAHAAN
}

\section{THE EFFECT OF OWNERSHIP STRUCTURE, CAPITAL STRUCTURE, AND DIVIDEND POLICY ON THE COMPANY VALUE}

\author{
Silvia Waning Hiyun Puspita Sari \\ Program Studi Manajemen Fakultas Ekonomi Universitas Alma ata \\ Yogyakarta \\ email: silviawaninghiyunp@gmail.com
}

\begin{abstract}
ABSTRAK
Penelitian ini bertujuan untuk menguji teori keagenan di Pasar modal Indonesia. Konflik keagenan dalam penelitian ini diproksi dengan nilai perusahaan (Tobins Q), sedangkan mekanisme pengendali konflik keagenan diproksi dengan kepemilikan institusional, leverage dan kebijakan dividen. Dalam penelitian ini peneliti menguji pengaruh ketiga variabel endogen. Data yang digunakan dalam penelitian ini adalah data sekunder yang bersumber pada Bursa Efek Indonesia, Osiris, IDX, dan Blommberg yakni semua perusahaan nonkeuangan yang memenuhi kriteria penyampelan dan terdaftar di Bursa Efek Indonesia pada periode pengamatan 2010-2014. Alat analisis yang digunakan dalam penelitian ini adalah regresi berganda.
\end{abstract}

Kata kunci: Kepemilikan Institusional, Leverage, Kebijkan Dividen, Nilai Perusahaan, Konflik Keagenan, Regresi berganda.

\section{ABSTRACT}

This study aims to examine agency theory in the Indonesian capital market. Agency conflict in this study is proxied by firm value (Tobins Q), while the agency conflict control mechanism is proxied by institutional ownership, leverage, and dividend policy. In this study, the researchers examined the effect of the three endogenous variables. The data used in this study are secondary data sourced from the Indonesia Stock Exchange, Osiris, IDX, and Blommberg, namely all non-financial companies that meet the screening criteria and are listed on the Indonesia Stock Exchange in the 2010-2014 observation period. The analytical tool used in this study is multiple regression.

Keywords: Institutional Ownership, Leverage, Dividend Policy, Company Value, Agency Conflict, Multiple Regression. 


\section{PENDAHULUAN}

Fokus utama dalam kebanyakan literatur penelitian adalah mengenai tata kelola perusahaan khususnya peran struktur kepemilikan sebagai mekanisme tata kelola perusahaan. Jenis masalah struktur kepemilikan dan apa implikasinya bagi tata kelola perusahaan masih menjadi pertanyaan. Banyak perhatian telah difokuskan pada hubungan antara struktur kepemilikan dan kinerja perusahaan. Pemisahan antara kepemilikan dan kontrol perusahaan menciptakan konflik kepentingan antara pemegang saham dan manajer yang (agency conflict) bisa mengejar tujuan-tujuan lain yang berbeda dari pemegang saham dalam memaksimalisasi kekayaan.

Dalam konteks agency cost model yang dikembangkan oleh Jensen dan Meckling (1976), kebijakan dividen digunakan untuk meminimilasi agency cost yang timbul dari potensi conflict of interest antara agent (manajer) dengan principal (pemilik perusahaan) akibat adanya pemisahan diantara kedua belah pihak tersebut. Dasar dari agency cost model adalah ketika manajer disadari bisa bertindak tidak sesuai dengan kepentingan investor/pemegang saham, maka pemegang saham menggunakan mekanisme tertentu untuk mengontrol tindakan manajer tersebut. Kebijakan dividen akan dilihat dari komponen dividend payout ratio, yang mengindikasikan jumlah dividen yang dibayarkan perusahaan dibandingkan dengan laba perusahaan. semakin besar dividen yang dibagikan maka menunjukkan nilai perusahaan semakin tinggi. Dividen yang tinggi dapat digunakan sebagai upaya untuk meminimalkan masalah keagenan. Hal ini disebabkan DPR yang tinggi bisa menyebabkan rasio laba ditahan kecil dan perusahaan menambah dari sumber eksternal, penambahan dari eksternal akan menyebabkan kinerja perusahaan dimonitor oleh pihak luar. Pengawasan inilah yang membuat manajer bertindak sesuai kepentingan pemegang saham sehingga masalah keagenan dapat dikurangi dan nilai perusahaan akan semakin baik.

Struktur kepemilikan (ownership structure) merupakan struktur kepemilikan saham perusahaan yang dilihat dari indikator insider's holding (managerial holding) dan institutional holding. Insider's holding (managerial holding) merupakan porsi kepemilikan saham perusahaan oleh orang dalam perusahaan (pihak manajemen) relatif terhadap total saham perusahaan yang beredar. Penelitian ini berfokus pada kepemilikan institusional saja karena sangat kecil sekali presentase kepemilikan saham yang dimiliki oleh manajer. Institutional holding (Institutional ownership) merupakan porsi atau persentase dari saham perusahaan yang dimiliki oleh badan atau lembaga terhadap total saham yang dikeluarkan oleh perusahaan dan sekaligus juga mencerminkan large block shareholding. Jensen dan Meckling (1976) mengemukakan bahwa agency cost akan rendah didalam perusahaan dengan kepemilikan manajerial (managerial ownership) yang tinggi, karena hal ini memungkinkan adanya penyatuan antara kepentingan pemegang saham dengan kepentingan manajer yang dalam hal ini berfungsi sebagai agent dan sekaligus sebagai principal. Rasionalnya adalah bahwa dengan managerial ownership atau insider owneship yang tinggi agency problem menjadi rendah antara manajer dengan pemegang saham.

Namun, pada perusahaan-perusahaan di Indonesia kepememilikan manajerial sangat kecil keberadaannya dan banyak hasil penelitian yang menemukan hasil yang tidak signifikan. Oleh karena itu penelitian ini hanya menggunakan kepemilikan institusional sebagai indikator dari struktur kepemilikan karena kepemilikan institusional di Indonesia memiliki presentase yang cukup besar. Investor Institutional sebagai monitoring agent, yang mana akan mendorong peningkatan pengawasan yang lebih optimal terhadap kinerja manajemen, serta atas proses distribusi saham antara pemegang saham dari luar, yaitu Institutional ownership dapat mengurangi agency cost Wahidawati (2001) dalam Rosidi (2007). Oleh karena itu peneliti tertarik untuk mengetahui apakah kepemilikan institusional di Indonesia dapat meningkatkan kinerja perusahaan. 
Mekanisme kontrol yang mampu menyelaraskan perilaku manajerial adalah melalui penggunaan utang yang optimal. Perusahaan yang memiliki struktur modal lebih banyak melibatkan utang (dari kreditur), maka akan lebih intensif pula pengawasan yang dilakukan oleh kreditur terhadap manajemen. Hal ini menjelaskan bahwa semakin tinggi penggunaan utang maka akan lebih intensif pula pengawasan yang dilakukan oleh kreditur terhadap manajemen karena dengan penggunaan hutang perusahaan akan memiliki kewajiban untuk membayar pinjaman dan membayar bunga secara periodik. Kondisi ini akan membuat perusahaan meningkatkan kinerjanya agar segera menutupi kewajibannya dan terhindar dari financial distress.

Mengikuti Jensen dan Meckling (1976), banyak literatur telah dikembangkan untuk menguji pengaruh dari manajemen dan perilaku mereka pada kinerja dan nilai perusahaan yang mereka kendalikan. Literatur mengenai hubungan antara tingkat kepemilikan manajerial, keputusan investasi yang dibuat oleh manajemen yang tidak bisa dipisahkan dengan nilai perusahaan, sebagai proksi dari rasio Tobin's Q. Beberapa peneliti juga memberikan bukti bahwa konflik keagenan dapat munurunkan nilai perusahaan (Shleifer dan Vishny, 1986 dan Ang, et al, 2000). Nilai perusahaan akan berdampak pada kinerja perusahaan dan akhirnya berdampak pada kemakmuran pemegang saham maka konflik keagenan harus dikurangi.

Berdasarkan uraian permasalahan, konflik keagenan dapat diminimalisir dengan tiga mekanisme, yaitu: struktur kepemilikan, leverage dan kebijakan dividen. Dengan mengunakan tiga mekanisme tersebut diharapkan dapat mengetahui bagaimana pengaruhnya terhadap kinerja perusahaan di negara Indonesia.

\section{RUMUSAN MASALAH}

Rumusan masalah dari penelitian ini adalah sebagai berikut:

1. Apakah struktur kepemilikan memiliki pengaruh terhadap nilai perusahaan?

2. Apakah leverage memiliki pengaruh terhadap nilai perusahaan?

3. Apakah deviden memiliki pengaruh terhadap nilai perusahaan?

\section{TEORI DAN PENGEMBANGAN HIPOTESIS Teori Keagenan}

Jensen dan Meckling (1976) mendefinisikan hubungan keagenan sebagai suatu kontrak yang mana satu atau lebih principal (pemilik) menggunakan orang lain atau agent (manajer) untuk menjalankan aktivitas perusahaan. Di dalam teori keagenan, yang dimaksud dengan principal adalah pemegang saham atau pemilik, sedangkan agent adalah manajemen yang mengelola harta pemilik. Dengan demikian ada potensi besar akan terjadinya perbedaan tujuan antara pemilik dan manajer. Keduanya ingin memaksimalkan kesejahteraan masingmasing. Pemisahan control dan kepemilikan inilah yang menyebabkan konflik keagenan (Jensen dan Meckling, 1976).

\section{Struktur Kepemilikan}

Struktur kepemilikan merupakan proporsi kepemilikan saham yang dimiliki oleh pihak tertentu. Struktur kepemilikan di Indonesia dibagi menjadi lima berdasarkan klasifikasi pemegang saham, yaitu kepemilikan manajerial, kepemilikan institusional, kepemilikan individu, kepemilikan publik dan kepemilikan pemerintah. Penelitian ini menggunakan kepemilikan institusional saja karena presentase kepemilikan institusional di Indonesia cukup besar.

Prinsip tata kelola perusahaan dan mekanisme eksternal dan internal yang dirancang untuk melindungi pemegang saham serta pemangku kepentingan memberikan dukungan kelembagaan dan berorientasi pasar yang tepat. Zhuang (1999) berpendapat bahwa struktur kepemilikan merupakan salah satu faktor yang paling penting dalam membentuk sistem tata kelola perusahaan dari negara manapun. Hal ini karena akan menentukan sifat 
dari masalah keagenan (agency problem). Zhuang (1999) mengidentifikasi dua aspek penting dari struktur kepemilikan perusahaan sebagai konsentrasi dan komposisi. Tingkat konsentrasi kepemilikan di sebuah perusahaan menentukan bagaimana kekuasaan didistribusikan antara pemegang saham dan manajer, sedangkan komposisi kepemilikan mencoba untuk menentukan siapa pemegang saham dan siapa diantara mereka milik kelompok pengendali.

Dari sudut pandang perusahaan, kepemilikan institusional mampu mengurangi konflik keagenan. Ketika perusahaan dimiliki oleh institusional maka perusahaan akan sangat dikontrol secara eksternal sehingga jika perusahaan memutuskan untuk membayar dividen maka hal tersebut terjadi jika perusahaan telah melakukan investasi dan memperbaiki kinerja perusahaan kepada perusahaan sehingga dana yang tersisa tersebutlah yang digunakan untuk membayar dividen.

Dalam hal ini utang dan kepemilikan institusional mampu memberikan efek keagenan dimana bahwa biaya agensi mengalami penurunan ketika terjadi penurunan atas pilihan pembiayaan dengan menggunakan utang karena manajer dalam melakukan keputusan menggunakan utang untuk pembiayaan juga melihat pada kepentingan investor institusional.

Hasil penelitian selanjutnya adalah dari Sisca (2008) menemukan Institusional Holding berpengaruh negatif terhadap kebijakan inisiasi dividen dan signifikan. Semakin tinggi kepemilikan saham oleh institusional maka semakin rendah dividen yang dibagikan. Hal ini dikarenakan semakin kuat kontrol eksternal terhadap perusahaan sehingga dapat mengurangi biaya keagenan.

Dari uraian para peneliti terdahulu dan berbagai teori yang dapat dirumuskan hipotesis sebagai berikut:

H1: Struktur kepemilikan Institusional memiliki pengaruh positif terhadap nilai perusahaan.

\section{Deviden}

Kebijakan dividen menurut Easterbrook (1984) dan Rozeff (1982) dalam Sugeng (2009) dapat digunakan sebagai upaya untuk meminimalkan agency conflict antara manajer dan shareholder. Dividen merupakan rasio yang positif artinya semakin besar dividen maka kesejahteraan pemegang saham juga semakin besar. Peningkatan dividen diharapkan dapat mengurangi biaya keagenan. Hal ini disebabkan dividend payout ratio (DPR) besar bisa menyebabkan rasio laba ditahan kecil dan perusahaan menambah dana dari sumber eksternal. Penambahan dana dari luar (utang) akan menyebabkan kinerja manajer dimonitor oleh bursa, komisi sekuritas dan penyedia dana baru. Pengawasan ini akan menyebabkan manajer bertindak sesuai kepentingan pemegang saham sehingga mengurangi biaya keagenan.

Kebijakan dividen merupakan salah satu keputusan perusahaan yang ditemukan dipengaruhi oleh struktur kepemilikan perusahaan. Hal ini dapat digunakan untuk mengurangi masalah keagenan di perusahaan, sehingga menggantikan kepemilikan besar sebagai alat monitoring. Disisi lain, pemegang saham besar bisa menggunakan kekuasaan mereka untuk mengambil alih sumber daya perusahaan untuk konsumsi pribadi mereka sendiri.

Dari uraian para peneliti terdahulu dan berbagai teori yang dapat dirumuskan hipotesis sebagai berikut :

H2: Deviden memiliki pengaruh positif terhadap nilai perusahaan.

\section{Leverage}

Penggunaan utang diharapkan dapat mengurangi konflik keagenan karena dengan menggunakan utang perusahaan akan memiliki kewajiban untuk mengembalikan pinjaman dan membayar beban bunga secara periodik. Kondisi ini akan menyebabkan manajer bekerja keras untuk meningkatkan laba untuk melunasi utangnya. Sebagai konsekuensinya 
dari kebijakan perusahaan menghadapi risiko kebangkrutan. Tingkat risiko inilah dapat mengurangi konflik keagenan.

Tujuan manajemen struktur modal adalah memadukan sumber-sumber dana permanen yang digunakan perusahaan untuk operasionalnya yang akan memaksimumkan nilai perusahaan itu sendiri. Pencarian struktur modal yang optimal merupakan pekerjaan yang sangat sulit, karena adanya konflik yang mengarah kepada biaya agensi.

Dari uraian para peneliti terdahulu dan berbagai teori yang dapat dirumuskan hipotesis sebagai berikut:

H3: Leverage memiliki pengaruh positif terhadap nilai perusahaan..

Model penelitian ini digambarkan seperti Gambar 1.

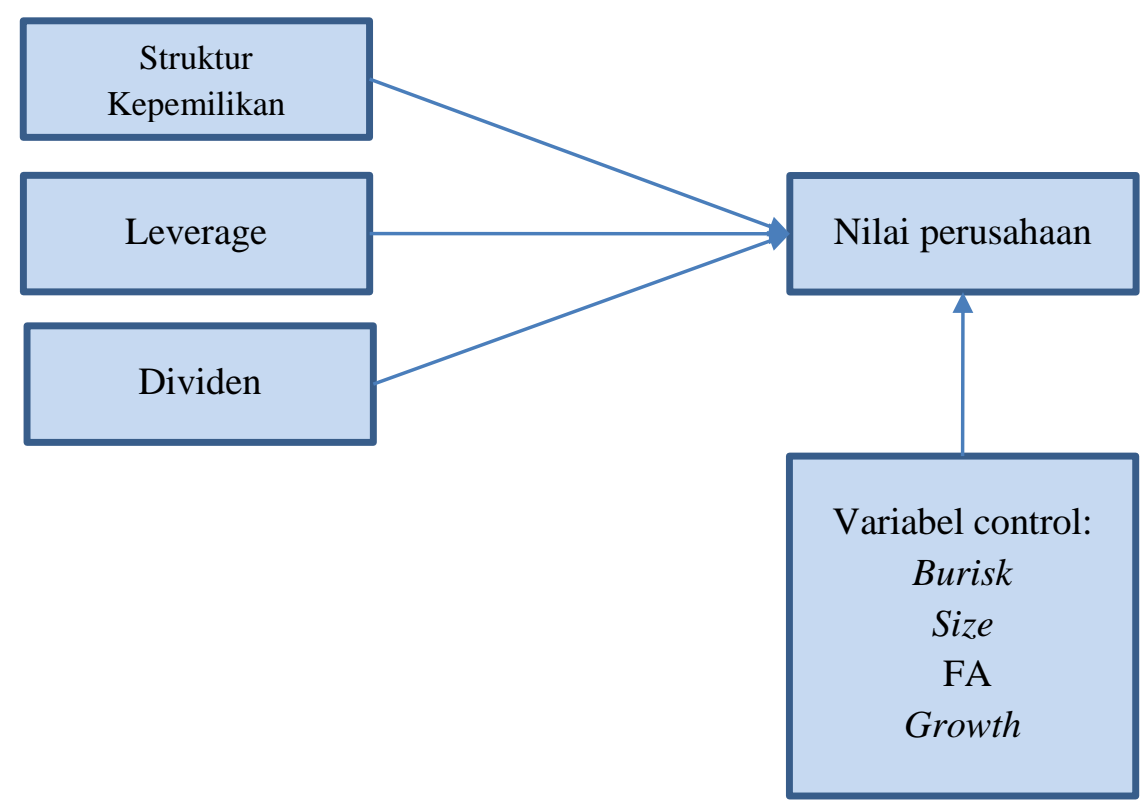

Gambar 1. Bagan model penelitian

Selain variabel utama atau variabel endogen yang digunakan dalam penelitain ini, peneliti juga menggunakan variabel eksogen untuk memperkuat penelitian yang akan dilakukan.

Business Risk. Pengaruh risiko terhadap kepemilikan institusional adalah negatif. Besarnya kepemilikan institusional maka berbanding lurus dengan kendali yang dilakukan pihak eksternal perusahaan sehingga akan meminimalisir biaya keagenan dan juga. Pemegang saham insitusi memiliki keuntungan yang lebih besar untuk memantau dan mengontrol manajemen dan pengambilan keputusan atau kebijakan perusahaan. Semakin besar kontrol yang dilakukan dari institusi maka kemungkinan akan dapat mengurangi perilaku manajemen yang tidak diinginkan sehingga akan mengurangi biaya keagenan.

Selanjutnya penggunaan utang dapat mengurangi konflik keagenan. Risiko mempunyai hubungan negatif terhadap utang (Chen dan Steiner, 1999). Perusahaan dengan risiko tinggi akan menghindari penggunaan utang yang tinggi dalam mendanai aktivanya. Hal ini dikarenakan peningkatan risiko yang berkaitan dengan kesulitan dalam pengembalian utang (Chen dan Steiner ,1999). Menurut Cheng, Elyasiani, dan Jingyi (2011), perusahaan yang memiliki aliran kas stabil membayar dividen lebih tinggi dibandingkan perusahaan yang memiliki aliran kas tidak stabil. Aliran kas yang tidak stabil menunjukkan peningkatan tingkat risiko yang ditanggung oleh perusahaan. Kondisi tingkat risiko tinggi perusahaan membagi dividen dalam jumlah kecil karena sebagian keuntungan dialokasikan pada laba ditahan. Alokasi keuntungan ini digunakan sebagai sumber internal bagi kepentingan pertumbuhan. 
Keputusan menetapkan dividen kecil pada tingkat risiko tinggi dapat memperkecil konflik keagenan (Chen dan Steiner, 1999).

Size yang menunjukkan semakin besar aktiva tetap maka semakin besar aset yang dijaminkan untuk memperoleh tambahan utang (Titman dan Wessels, 1988) dalam Wardhana (2011). Jensen dan Meckling (1976) berargumen bahwa konflik keagenan cenderung terjadi pada perusahaan yang besar. Semakin besar ukuran perusahaan, maka semakin banyak manajer yang dibutuhkan untuk mengelola perusahaan dan seharusnya akan semakin tinggi kepemilikan manajerial agregat.

Aset tetap (Fixed Asset) menunjukkan struktur asset suatu perusahaan. Aset tetap diharapkan berhubungan positif dengan tingkat utang. Aset tetap yang dimiliki perusahaan dapat dijadikan jaminan. Hal ini berarti semakin tinggi asset tetap akan membuat perusahaan dipercaya oleh pemberi utang (debtholders).

Fixed asset dapat menjadi jaminan ketika akan mencari sumber pendanaan dari utang. Hubungan yang positif antara asset tetap dan utang sesuai dengan hasil penelitan Crutchley, Jensen, Jahera dan Raymond (1999).

Petumbuhan perusahaan (Growth), Timtan dan Wessels (1988) dalam Wardhana (2011) berargumen bahwa perusahaan yang pertumbuhannya tinggi mengindikasikan fleksibilitas dalam investasi di masa depannya dan semakin besar kesempatan manajemen melakukan ekspropiari terhadap kreditur. Dengan demikian, pertumbuhan perusahaan akan memiliki pengaruh negatif terhadap kebijakan utang. Terkait dengan kepemilikan institusional, pertumbuhan akan memiliki pengaruh yang positif. Hal ini disebabkan adanya informasi tentang prospek perusahaan, khususnya prospek pertumbuhan perusahaan. Manajer lebih mengetahui tentang proyek yang diambil oleh perusahaan. Pemilik institusional dengan proporsi kepemilikan yang tinggi dan manajer merupakan pihak internal memiliki informasi mengenai kinerja dan risiko perusahaan. Pada saat menghadapi peningkatan risiko pihak internal akan mengendalikan persentase kepemilikan sahamnya.

\section{METODE PENELITIAN}

\section{Sumber Data Dan Sampel}

Data penelitian diperoleh dari Bursa Efek Indonesia, Bloomberg, Osiris, dan IDX. Penelitian ini menggunakan metode purposive sampling untuk menentukan sampel. Adapun kriterianya adalah sebagai berikut:

1. Semua perusahaan (non keuangan) yang terdaftar di Bursa Efek Indonesia selama periode pengamatan 2010-2014.

2. Data yang diperlukan tiap perusahaan adalah kebijakan dividen, leverage dan struktur kepemilikan institusional, dan Tobin $\mathrm{Q}$ beserta variabel kontrolnya seperti: business risk, size, fixed asset, dan growth.

\section{Definisi Operasional Variable Tobin's $\mathbf{Q}$}

Perbedaan rasio Tobin's $Q$ merefleksikan kemampuan perusahaan untuk menciptakan nilai tambah bagi pemegang saham dengan jumlah asset tertentu. Tobin's Q didefinisikan sebagai rasio nilai pasar perusahaan dibandingkan dengan replacement cost dari asetnya. Variabel ini diberi simbol Q, yang dihitung dengan menggunakan rasio Tobin's Q yang dikembangkan oleh Himmelberg, Hubbard dan Palio (1999) dan Chen et al (2006) yaitu:

\section{Keterangan:}

$$
\boldsymbol{Q}=\frac{(\boldsymbol{P})(\boldsymbol{N})+\boldsymbol{D}}{\boldsymbol{B V} \boldsymbol{A}}
$$

$$
\begin{array}{ll}
\mathrm{Q} & =\text { Nilai Perusahaan } \\
\mathrm{P} & =\text { Harga pasar saham } \\
\mathrm{N} & =\text { Jumlah saham yang beredar }
\end{array}
$$


$\mathrm{D} \quad=$ Nilai buku total hutang

BVA = Nilai buku total aktiva

\section{Kebijakan Dividen}

Kebijakan dividen adalah keputusan apakah laba yang diperoleh perusahaan sebaiknya dibagikan kepada pemegang saham dalam bentuk dividen ataukah laba tersebut sebaiknya ditahan dalam bentuk laba ditahan guna pembiayaaan investasi di masa mendatang. Kebijakan dividen menggunakan indikator dividend payout ratio. DPR adalah besarnya dividen yang dibagikan kepada investor (Dividend Payout Ratio).

$$
D P R=\frac{D P S}{E P S} x 100 \%
$$

\section{Institutional Ownership}

Kepemilikan Institusional merupakan proporsi kepemilikan saham pada akhir tahun yang dimiliki oleh lembaga, seperti asuransi, bank atau institusi lain. Variabel ini diukur dari jumlah presentase saham yang dimiliki oleh institusi terhadap jumlah saham yang beredar Adapun teknik analisisnya:

$$
I O=\frac{\sum \text { Saham milik institusi }}{\sum \text { saham beredar }} X 100 \%
$$

\section{Leverage}

Rasio ini merupakan rasio pertama dan paling menyeluruh dalam perbandingan utang, baik jangka pendek maupun jangka panjang terhadap aktiva total.

$$
\text { Leverage }=\frac{\text { Total Utang }}{\text { Total Aktiva }} \quad x 100 \%
$$

\section{Business Risk}

Chen, steiner dan Whyte (1998) dalam Nuringsih (2002) menyatakan bahwa peningkatan risiko menyebabkan manajer mengurangi kepemilikan saham dan memilih berinvestasi pada kesempatan lain. Risiko dan kepemilikan manajerial memiliki pengaruh terhadap konflik keagenan. Peningkatan kepemilikan manajerial menyebabkan peningkatan risiko sehingga menurunkan penggunaan utang dan dividen. Untuk mengukur busrisk menggunakan laba perusahaan 10 tahun terakhir.

$$
\text { BUSRISKit }=\text { STD RETit }
$$

\section{Size (Ukuran Perusahaan)}

Semakin besar aktiva tetap maka semakin besar aset yang dijaminkan untuk memperoleh tambahan utang (Titman dan Wessels, 1988) dalam Wardhana (2011). Jensen dan Meckling (1976) berargumen bahwa konflik keagenan cenderung terjadi pada perusahaan yang besar. Semakin besar ukuran perusahaan, maka semakin banyak manajer yang dibutuhkan untuk mengelola perusahaan dan seharusnya akan semakin tinggi kepemilikan manajerial agregat. Untuk mengukur ukuran perusahaan dapat dirumuskan sebagai berikut:

Keterangan:

$$
\text { SIZE = Log Total Asset }
$$

Size $\quad=$ ukuran perusahaan

Log. Total Asset = Logaritma total asset perusahaan 


\section{Aset tetap (Fixed Asset)}

Aset tetap menunjukkan struktur asset suatu perusahaan. Aset tetap diharapkan berhubungan positif dengan tingkat utang. Aset tetap yang dimiliki perusahaan dapat dijadikan jaminan. Hal ini berarti semakin tinggi asset tetap akan membuat perusahaan dipercaya oleh pemberi utang (debtholders). Fixed asset dapat menjadi jaminan ketika akan mencari sumber pendanaan dari utang. Hubungan yang positif antara asset tetap dan utang sesuai dengan hasil penelitan Crutchley, Jensen, Jahera dan Raymond (1999). Untuk mengukur asset tetap digunakan rumus sebagai berikut:

$$
F A=\frac{\text { Asset tetap }}{\text { Total asset }}
$$

\section{Petumbuhan Perusahaan (Growth)}

Timtan dan Wessels (1988) dalam Wardhana (2011) berargumen bahwa perusahaan yang pertumbuhannya tinggi mengindikasikan fleksibilitas dalam investasi di masa depannya dan semakin besar kesempatan manajemen melakukan ekspropiari terhadap kreditur. Dengan demikian, pertumbuhan perusahaan akan memiliki pengaruh negatif terhadap kebijakan utang. Terkait dengan kepemilikan institusional, pertumbuhan akan memiliki pengaruh yang positif. Hal ini disebabkan adanya informasi tentang prospek perusahaan, khususnya prospek pertumbuhan perusahaan. Manajer lebih mengetahui tentang proyek yang diambil oleh perusahaan.

Pemilik institusional dengan proporsi kepemilikan yang tinggi dan manajer merupakan pihak internal memiliki informasi mengenai kinerja dan risiko perusahaan. Pada saat menghadapi peningkatan risiko pihak internal akan mengendalikan persentase kepemilikan sahamnya. Untuk mengukur pertumbuhan perusahaan dihitung dengan menggunakan rumus:

\section{Persamaan Regresi}

$$
\text { Growth }=\frac{\text { price }}{\text { earning }} x 100 \%
$$

Penelitian ini akan menggunakan (least square) tiga tahap (3 SLS) pada suatu sistem persamaan yang mencakup satu persamaan untuk masing-masing kebijakan tersebut. Pengembangan dalam penelitian ini mengikuti bentuk klasik untuk pengestimasian persamaan struktural dengan variabel-variabel ownership, leverage dan dividend yang merupakan fokus dalam penelitian ini, kemudian tahap berikutnya menambahkan sebuah vektor variabel-variabel penjelas yang menangkap atribut-atribut riil perusahaan, dan mengestimasikan suatu sistem persamaan-persamaan struktural. Persamaan regresi dalam penelitian ini adalah sebagai berikut:

\section{Firm Value $=a_{1}+\beta_{1}$ IO $+\beta_{2}$ Lev $+\beta_{3}$ Dividen $+\beta_{4}$ Burisk $+\beta_{5}$ Size $+\beta_{6} F A+\beta_{7}$ Growth $+e_{i t}$}

\section{HASIL DAN PEMBAHASAN} Statistik Deskriptif

Tabel 1. Statistik Deskriprif

\begin{tabular}{lrrrrrrrr}
\hline Variabel & $\begin{array}{c}\text { Tobin_Q_ } \\
\text { Ratio }\end{array}$ & DPR & $\begin{array}{c}\text { Leverage_ } \\
\text { ratio }\end{array}$ & IO_Ratio & Growth & FA & BU_Risk & Size \\
\hline Mean & 1.705154 & 0.538162 & 0.293668 & 0.658271 & 0.496362 & 0.333018 & 4.391062 & 6.206091 \\
Median & 1.11895 & 0.307163 & 0.235923 & 0.680453 & 0.14431 & 0.308699 & 3.486549 & 6.200074 \\
Max & 32.0255 & 53.92743 & 4.83439 & 0.997315 & 48.60605 & 0.962587 & 20.81726 & 8.372965 \\
Min & 0.2559 & 0 & 0.000537 & 0.003452 & 0.003538 & 0 & 0.224246 & 3.522776 \\
Std. Dev. & 2.002871 & 2.37305 & 0.309924 & 0.218944 & 2.232128 & 0.243454 & 2.997141 & 0.766122 \\
\hline
\end{tabular}




\section{Pengujian Pengaruh Struktur Kepemilikan, Leverage, Kebijakan Dividen Terhadap Nilai Perusahaan}

Tabel 2 menggambarkan hasil regresi menggunakan fixed effect. Pengujian ini untuk mengetahui hubungan masing-masing variabel independen (Leverage_Ratio,IO_Ratio, Bu_Risk, DPR, FA, Growth dan Size,) terhadap variabel dependen (Tobin_Q_Ratio). Variabel leverage diproksikan dengan Leverage_Ratio yang diukur dengan total hutang dibagi total aktiva. Variabel kepemilikan Institusional diproksikan dengan IO_Ratio yang diukur dengan jumlah saham milik institusi dibagi jumlah saham yang beredar. Variabel Dividen diproksikan oleh DPR (Dividen payout ratio) yang diukur dengan rasio antara dividen yang dibayarkan sebuah perusahaan (dalam satu tahun buku) dibagi dengan keuntungan bersih perusahaan (net income). Variabel Risiko bisnis diproksikan dengan Bu_Risk yang diukur dengan standar deviasi dari return selama 10 tahun terakhir. Variabel ukuran perusahaan diproksikan dengan size yang diukur dengan log dari total aset yang dimiliki perusahaan. Variabel asset tetap diproksikan oleh FA yang diukur dengan asset tetap dibagi total asset. Dan variabel pertumbuhan perusahaan diproksikan oleh growthyang diukur oleh price/earning.

Tabel 2. Hasil Regresi Struktur Kepemilikan, Leverage, Kebijakan Dividen terhadap Nilai

\begin{tabular}{ccc}
\multicolumn{2}{c}{ Perusahaan } \\
Vependen & $\begin{array}{c}\text { Variabel } \\
\text { Independen }\end{array}$ & $\begin{array}{c}\text { Fixed } \\
\text { effect }\end{array}$ \\
\hline $\begin{array}{l}\text { Tobin_Q_Rati } \\
o\end{array}$ & IO_Ratio & $0.140650^{* * *}$ \\
& $(2.995693)$ \\
Leverage_Ratio & -0.064277 \\
& DPR & $(-1.620525)$ \\
& $0.011505^{* * *} *$ \\
Bu_Risk & $(3.716929)$ \\
& $0.008667 * * *$ \\
Size & $(4.930575)$ \\
& -0.000151 \\
FA & $(-0.013595)$ \\
& $0.059364 * * *$ \\
Growth & $(2.996244)$ \\
& 0.000983 \\
& $(0.992831)$
\end{tabular}

Dari Tabel 2 dapat diketahui bahwa kepemilikan institusional yang diproksikan dengan IO_Ratio memiliki hubungan positif dan signifikan terhadap nilai perusahaan yang diproksikan dengan Tobin_Q_Ratio. Hal ini menunjukkan bahwa semakin besar perusahaan melibatkan kepemilikan institusional maka nilai perusahaan akan meningkat. Peningkatan kepemilikan institusional mengakibatkan kinerja perusahaan diawasi secara optimal dan terhindar dari perilaku opportunistik. Dengan melibatkan pihak institusional lebih besar, maka manajer akan bertindak sesuai keinginan pemegang saham sehingga dapat mengurangi masalah keagenan. Kepemilikan institusi yang besar akan melakukan pengawasan secara aktif supaya manajer mengarahkan semua kebijakan dan usahanya untuk memaksimalkan nilai perusahaan.

Pada hasil pengujian ini ditemukan bahwa leverage memiliki pengaruh negatif namun tidak signifikan terhadap nilai perusahaan. Hal ini menunjukkan bahwa variabel hutang bukanlah penentu baik atau buruknya nilai suatu perusahaan. Hal ini sejalan dengan hasil penelitian Donalson (1961) yang menemukan bahwa nilai perusahaan memiliki pengaruh negatif terhadap utang. Penggunaan utang akan meningkatkan nilai perusahaan tapi hanya sampai titik tertentu. Setelah titik optimalnya penggunaan utang justru akan akan menurunkan nilai 
perusahaan karena kenaikan keuntungan dari penggunaan utang tidak sebanding dengan kenaikan biaya financial distress dan agency problem.

Hasil diatas juga menunjukkan bahwa dividen yang dibagikan berpengaruh positif dan signifikan terhadap nilai perusahaan. Hal ini menunjukkan bahwa semakin besar dividen yang dibagikan maka menunjukkan nilai perusahaan semakin tinggi. Dividen yang tinggi dapat digunakan sebagai upaya untuk meminimalkan masalah keagenan. Hal ini disebabkan DPR yang tinggi bisa menyebabkan rasio laba ditahan kecil dan perusahaan menambah dari sumber eksternal, penambahan dari eksternal akan menyebabkan kinerja perusahaan dimonitor oleh pihak luar. Pengawasan inilah yang membuat manajer bertindak sesuai kepentingan pemegang saham sehingga masalah keagenan dapat dikurangi dan nilai perusahaan akan semakin baik.

Bu_Risk memiliki hubungan positif dan signifikan pada Tobin_Q_Ratio. Hal ini menunjukkan bahwa semakin tinggi tingkat risiko yang dimiliki oleh perusahaan maka akan mengakibatkan nilai perusahaan semakin meningkat. Hal ini ada kaitannya dengan kepemilikan institusional yang akan mengurangi masalah keagenan. Hasil ini menunjukkan bahwa peningkatan risiko yang semakin meningkat akan menyebabkan manajer mengurangi kepemilikan saham dan memilih berinvestasi pada kesempatan lain sehingga perusahaan akan meningkatkan kepemilikan institusional sebagai cara mengurangi konflik keagenan. Peningkatan jumlah kepemilikan institusional menyebabkan perusahaan memiliki pengawasan dan monitoring dari pihak luar, sehingga masalah keagenan bisa diminimalisir. Selain itu perusahaan akan termotivasi untuk meningkatkan kinerja perusahaan sehingga dapat mengatasi risiko tinggi.

Size memiliki hubungan negatif namun tidak signifikan terhadap nilai perusahaan. Hal ini menunjukkan bahwa bukan ukuran perusahaan yang memgakibatkan tinggi rendahnya nilai suatu perusahaan.

Fix asset memiliki hubungan positif dan signifikan pada nilai perusahaan. Hal ini menunjukkan bahwa semakin besar fix asset suatu perusahaan maka akan meningkatkan nilai suatu perusahaan karena semakin besar asset tetap yang dimiliki oleh perusahaan maka semakin besar asset yang dapat dijaminkan untuk memperoleh tambahan utang. Penggunaan utang dapat mengurangi masalah keagenan karena perusahaan dimonitor oleh pihak luar sehingga perusahaan berusaha memaksimalkan nilai perusahaannya.

Hubungan growth dan nilai perusahaan tidakdapat dijelaskan karena hasil yang diperoleh dari pengujian tidak signifikan. Hal ini menunjukkan bahwa pertumbuhan perusahaan tidak dapat menjelaskan nilai perusahaan.

\section{KESIMPULAN}

1. Kepemilikan institusional yang diproksikan dengan IO_Ratio memiliki hubungan positif dan signifikan terhadap nilai perusahaan yang diproksikan dengan Tobin_Q_Ratio. Hal ini menunjukkan bahwa semakin besar perusahaan melibatkan kepemilikan institusional maka nilai perusahaan akan meningkat.

2. Leverage memiliki pengaruh negatif namun tidak signifikan terhadap nilai perusahaan. Hal ini menunjukkan bahwa variabel hutang bukanlah penentu baik atau buruknya nilai suatu perusahaan

3. Deviden yang dibagikan berpengaruh positif dan signifikan terhadap nilai perusahaan. Hal ini menunjukkan bahwa semakin besar dividen yang dibagikan maka menunjukkan nilai perusahaan semakin tinggi. Dividen yang tinggi dapat digunakan sebagai upaya untuk meminimalkan masalah keagenan

\section{SARAN}

Berdasarkan hasil tersebut, maka dapat direkomendasikan untuk penelitian selanjutnya sebagai berikut 
1. Penelitian berikutnya dapat menggunakan proksi-proksi variabel yang lain untuk menguji hubungan pengaruh struktur kepemilikan, leverage, dan kebijakan dividen sehingga dapat memperkuat hasil penelitian.

2. Penelitian dapat melihat secara detail variabel-variabel kontrol lainnya yang mempengaruhi struktur kepemilikan, leverage, dan kebijakan dividen terhadap nilai perusahaan

\section{DAFTAR PUSTAKA}

Ang, J.S., Cole, RA dan Lin, J.W. 2000. "Agency cost and ownership structure". Journal of finance. 55/1, 81-106.

Chen, Carl. R., dan Steiner, Thomas. L. 1999. "Managerial Ownership and Agency Conflict: A Nonlinear Simultaneous Equation Analysis of Managerial Ownership, Risk Taking, Debt Policy, and Dividend Policy". Financial Review, Vol. 34, Pp. 119-137.

Cheng, Jiang, Elyasiani, Elyas dan Jingyi (Jane) Jia. 2011. "Institutional Ownership Stability and Risk Taking: Evidence from the Life-Health Insurance Industry". The Journal of Risk and Insurance. Vol. 78, No. 3, Pp. 609-641.

Crutchley, E. Claire, Jensen, Marlin R.H, Jahera, John S. dan Raymond, Jennie E. 1999. Agency Problems and the Simultaneity of Financial Decision Making: The Role of Institutional Ownership.International review of financial analysis, Vol.8, No. 2, pp.177197

Jehsen, M.C., and Meckling, W.H. 1976. "Theory of the Firm: Managerial Behavior, Agency Cost and Ownership Structure". Journal of financial economics, pp 305-360.

Jensen, G.R., Solberg, D.P., and Zorn, T.S., 1992. "Simultaneous Determination of Insider Ownership, Debt, and Dividen Policies", Journal of Fiancial and Quantitative Analysis 27, 247-263.

Kale, J.R. and T.H. Noe, "Dividend, Uncertainty, and Underwriter Cost Under Asymmetric Information", Journal of Financial Research, 13, 1990, hlm 256-277.

Rosidi, Achmad Fauz. 2007. Pengaruh Aliran Kas Bebas, Kepemilikan Manajerial, Kepemilikan Institusional, Kebijakan Hutang dan Collateral Asset terhadap Kebijakan Dividen. Jurnal Ekonomi dan Manajemen. 8 (2) : 259-267.

Shleifer, A., dan Vishny R.W., 2000, "Large Shareholders and Corporate Control", Journal of Political Economy 94, 461-488

Sugeng, Bambang.2009 Pengaruh Struktur Kepemilikan dan Struktur Modal terhadap Kebijakan Inisiasi Dividen Di Indonesia.Jurnal Ekonomi Bisnis. 1(3) : 37- 48.

Wardhana, Leo Indra. 2011. Kepemilikan Institusional dan Mekanisme Pengendali Konflik Keagenan". Thesis.Universitas Gadjah Mada.

Zhuang, J. 1999. Some conceptual issues of corporate governance. EDRC Briefing Notes Number 13.Diakses pada 10 Mei 2017, dari www.adb.org/Documents/Books/Corporate Governance/Vol1/chapter2.pdf. 